\title{
PENGEMBANGAN SOAL STATISTIKA BERBASIS MICROSOFT POWER POINT VISUAL BASIC FOR APPLICATION (VBA)
}

\author{
lesyah Rodliyah ${ }^{1 *}$, Sari Saraswati ${ }^{2}$ \\ ${ }^{1,2}$ Fakultas IImu Pendidikan, Universitas Hasyim Asy'ari Tebuireng Jombang \\ *iesyahrodliyah90@gmail.com
}

Received: July $07^{\text {th }}, 2021$

Revised: August 01 ${ }^{\text {st }}, 2021$

Accepted: August $04^{\text {th }}, 2021$

\begin{abstract}
The purpose of this study is to describe the results of the development of statistical questions presented by utilizing Microsoft Power Point applications based on Visual Basic for Applications. The development model in this study uses the ADDIE model which stands for analysis, design, development, implementation, and evaluation. This research trial used several subjects including two validators, namely material experts and media experts, as well as mathematics education students who took statistics courses. Data collection techniques were carried out through test and questionnaire methods. While the data analysis technique used quantitative descriptive analysis. This development research resulted in a product in the form of statistical test questions in the form of multiple choice questions consisting of five questions and packaged in a macro VBA-based Microsoft Power Point application. The results showed that the questions developed met the valid, reliable, and sensitive categories. In addition, the products developed have also met the criteria of being valid, practical, and effective for use.
\end{abstract}

Keywords: ADDIE; Microsoft Power Point; Statistics; VBA

\section{PENDAHULUAN}

Pada abad ke-21 ini sasaran disrupsi yang sangat menonjol adalah institusi khususnya universitas. Universitas-universitas di Indonesia semakin tidak berbunyi di Asia. (Kasali, 2018). Kurangnya inovasi menjadi salah satu faktor yang menyebabkan hal tersebut. Inovasi merupakan ide-ide baru yang benar-benar diterapkan secara mendasar dengan cara yang berbeda untuk menghasilkan nilai baru dan/atau tambahan. Inovasi menjadi suatu kepentingan bersama, bukan hanya pembuat ide atau organisasi. Pada saat ini, sejumlah negara telah mengadopsi inovasi sebagai agenda nasional menuju kemajuan bangsa dan negara (Lee \& Trimi, 2018). Serdyukov (2017) menambahkan bahwasanya berinovasi berarti melihat apa yang sedang dilakukan dan mengembangkan ide baru yang membantu pekerjaan dengan cara baru. Oleh karena itu, tujuan dari 
setiap penemuan adalah untuk menciptakan sesuatu yang berbeda dari apa yang telah dilakukan, baik secara kualitas atau kuantitas atau keduanya. Inovasi berkaitan dengan beberapa nilai yang praktis di dunia. Diantaranya membahas bagaimana membuat alat, produk, atau proses baru, menghasilkan sesuatu yang baru yang menjadikan manusia mencapai tujuan tertentu yang sebelumnya tidak mampu dicapai.

Di dalam dunia pendidikan khususnya di Universitas Hasyim Asy'ari perlu inovasi untuk mendukung kemajuan institusi terlebih lagi pada abad ke-21. Salah satu yang perlu dilakukan inovasi adalah cara mengevaluasi hasil belajar peserta didik khususnya mahasiswa. Menurut Rahayu (2021), Evaluasi diperlukan untuk memberikan informasi tentang kekurangan dalam perancangan sistem implementasi, yang akan menghasilkan arah perbaikan pembelajaran. Sejalan dengan pendapat Almutairi dan Shraid (2021) menambahkan bahwa evaluasi digunakan untuk merujuk pada apa yang telah dicapai dan apa yang dibutuhkan untuk mengembangkan atau meningkatkan kinerja juga sebagai gambaran yang membantu para pendidik atau pembuat kebijakan atau pengawas atau pemangku kepentingan lainnya untuk mencari tahu tentang hasil pengajaran yang telah dilaksanakan. Merancang suatu evaluasi hasil belajar dengan cara yang inovatif merupakan salah satu alat penting untuk mengatasi masalah ini. Terutama dilakukan oleh organisasi akademis, agar proses evaluasi efektif perlu lebih banyak dilakukan oleh para profesional desain (Sharpe, 2018). Di Universitas Hasyim Asy'ari proses evaluasi hasil belajar kebanyakan masih dilakukan dengan cara konvensional/tertulis yang menjadikan kurang efisiensi waktu. Terlebih lagi apabila jumlah mahasiswa yang semakin banyak, proses evaluasi akan semakin menjadi kurang efisien baik itu kurang efisiennya waktu dan tenaga. Namun karena adanya pandemi covid 19, proses evaluasi hasil belajar sudah mulai menggunakan berbagai aplikasi. Aplikasi yang sudah mulai digunakan yaitu menggunakan google form, wondershare quiz creator, dan hot potatoes, exam views, quizziz.

Berbagai aplikasi yang ada dan tersedia, ada satu aplikasi yang sangat ramah untuk digunakan karena aplikasi ini sangat user friendly. Selain itu, pengguna tidak perlu lagi untuk menginstal software tersebut. Aplikasi ini sudah 
tersedia di setiap PC yaitu Microsoft Power Point, namun pada penggunaanya untuk evaluasi hasil belajar perlu dilakukan inovasi dengan menggunakan macro Visual Basic for Application atau biasa disingkat dengan Macro VBA. Aplikasi ini adalah software yang sudah didesain secara khusus untuk menyajikan tampilan program multimedia yang menarik, mudah dibuat dan mudah digunakan. VBA atau makro adalah fungsi atau perintah program di Microsoft office yang disimpan di visual basic lama. VBA memungkinkan Microsoft office untuk bekerja secara maksimal (Wijaya, Ying, Cunhua, \& Zulfah, 2020). Sedangkan Microsoft Power Point berbasis VBA dibuat supaya media menjadi lebih interaktif serta mampu mendeskripsikan hasil belajar peserta didik setelah selesai mengikuti proses kegiatan belajar mengajar agar lebih efisien. Dilmurodovna (2020) menambahkan bahwa Penggunaan macro pada bahasa pemrograman Visual Basic for Application (VBA) pada aplikasi di Microsoft Office adalah topik unik dan terpisah dalam studi ilmu komputer. Di satu sisi, pemrograman makro di VBA menciptakan banyak kemungkinan yang tidak bisa dicapai dengan menggunakan alat standar aplikasi perkantoran.

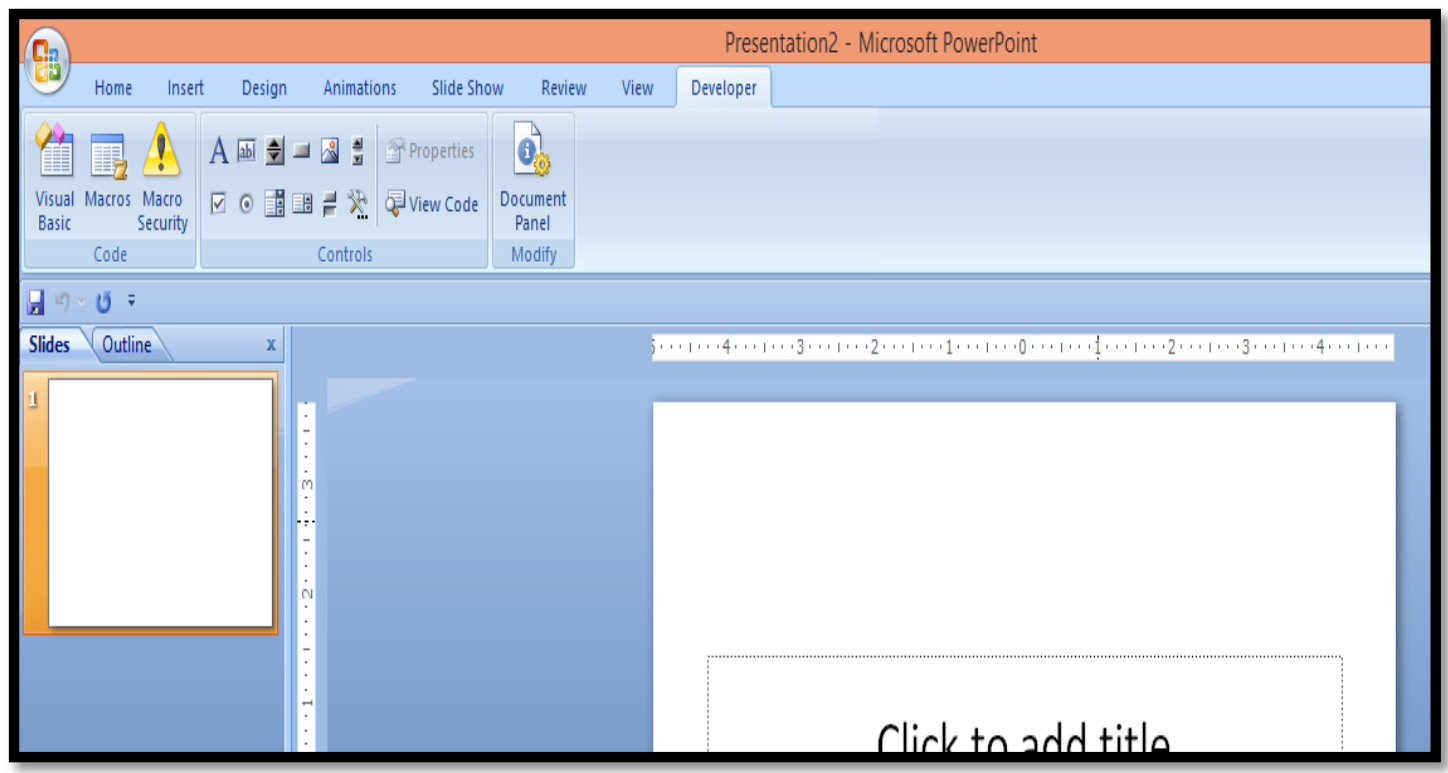

Gambar 1. Microsoft Power Point dengan Menu VB pada Tool Bar

Microsoft Power Point dengan menggunakan macro VBA salah satu media interaktif yang bisa dimanfaatkan untuk proses evaluasi hasil belajar mahasiswa terutama pada masa pandemi covid 19 saat ini. Inovasi media interaktif berupa 
proses mengevaluasi hasil belajar peserta didik menjadi alat bantu (tool) bagi pendidik untuk melakukan evaluasi pembelajaran lebih efisien, sehingga dapat diketahui dengan mudah hasil belajar siswa serta dengan begitu bisa ditentukan hasil presentase mahasiswa yang telah tuntas dan seberapa sulit atau mudah soal yang diberikan, sehingga tingkat ketercapaian mahasiswa dalam belajar lebih terukur dengan mudah. Berdasarkan pemaparan ini, peneliti tertarik untuk mengembangkan Soal statistika yang disajikan pada aplikasi Microsoft power point berbasis macro VBA sebagai alat untuk mengevaluasi hasil belajar statistika di UNHASY khususnya pada mahasiswa pendidikan matematika.

Beberapa penelitian yang relevan dengan penelitian ini adalah, penelitian yang dilakukan oleh Hasana dan Alifiani (2019) dengan judul Multimedia Development Using Visual Basic For Application (VBA) To Improve Students' Learning Motivation In Studying Mathematics Of Economics. Pada penelitian ini, menunjukkan bahwasanya penggunaan pengembangan multimedia dengan VBA dapat meningkatkan motivasi belajar siswa dalam belajar Matematika Ekonomi. Berikutnya ada penelitian yang telah dilakukan oleh Chotimah, Bernard, dan Wulandari (2018) dengan judul Contextual approach using VBA learning media to improve students' mathematical displacement and disposition ability. Hasil penelitian ini menjelaskan bahwa pencapaian dan peningkatan kemampuan penalaran dan disposisi matematis siswa yang pembelajarannya dengan pendekatan kontekstual didukung oleh media pembelajaran VBA (Visual Basic Application for Excel) lebih baik dibandingkan siswa yang mendapat pembelajaran konvensional. Selanjutnya penelitian yang dilakukan oleh Ruqoyyah, Murni, \& Wijaya, (2020) dengan judul The Effect of VBA for Microsoft Excel as Teaching Material to Improve Prospective Elementary School Teachers' Mathematical Conceptual Understanding. pada penelitian ini menjelaskan kelebihan menggunakan VBA lainnya yaitu pembelajaran menggunakan VBA mampu meningkatkan kemampuan pemahaman konsep matematika siswa, menjadikan siswa lebih antusias, aktif dan termotivasi dalam belajar matematika. Hal ini diperkuat dengan hasil penelitian yang telah dilakukan oleh Wijaya, dkk., (2020) dengan judul penelitian Using VBA for microsoft excel based on 6-questions cognitive theory in teaching fraction. Hasil penelitian tersebut juga menyatakan 
bahwasanya VBA for Microsoft excel berdasarkan teori kognitif 6 soal dapat meningkatkan kemampuan pemahaman siswa secara signifikan. Berdasarkan pemaparan dari beberapa penelitian, kelebihan pembelajaran menggunakan VBA mampu memberikan perubahan positif yang membuat para siswa menjadi lebih baik, baik dari segi kemampuan pemahaman maupun keaktifan dalam kegiatan pembelajaran.

Berdasarkan pemaparan terkait penelitian sebelumnya yang relevan, Pada penelitian ini akan dikembangkan soal statistika sebagai evaluasi hasil belajar mahasiswa pendidikan matematika UNHASY yang telah mengikuti perkuliahan ini menggunakan aplikasi VBA tersebut, sebagai upaya inovasi baru dalam mengevaluasi hasil belajar di UNHASY yang sebelumnya masih sering menggunakan metode konvensional/mannual. Aplikasinya yang user friendly dan tanpa perlu menginstal lagi karena sudah ada di setiap PC serta bisa digunakan baik secara offline maupun online menjadi salah satu keunggulan menggunakan VBA dari aplikasi yang lain. Anomeisa, dan Ernaningsih, (2020) juga menambahkan bahwa menggunakan VBA menjadikan media pembelajaran Microsoft Power Point menjadi interaktif. Harapannya setelah menggunakan VBA proses evaluasi hasil belajar mahasiswa menjadi lebih efisien dan membuat mahasiswa lebih antusias dan aktif.

\section{METODE PENELITIAN}

\section{Jenis Penelitian}

Penelitian ini merupakan penelitian pengembangan dimana model pengembangan yang digunakan adalah model pengembangan ADDIE (lihat Febriyanti, \& Putra, 2020; Jalinus \& Alim, 2018; Putra, Wulandari, Alpusari, \& Hermita, 2021; Wahyuni \& Ananda, 2021). Model pengembangan ini merupakan satu dari model desain pembelajaran yang sistematis, dipilih berdasarkan pertimbangan model ini dikembangkan sistematis dan bertumpu pada landasan teoritis desain pembelajaran. Model ini terstruktur diprogramkan dengan rangkaian kegiatan yang sistematis dalam upaya memecahkan masalah pembelajaran yang berkaitan dengan sumber belajar yang sesuai dengan kebutuhan dan karakteristik peserta didik (Widyastuti, \& Susiana, 2019). 
ADDIE merupakan model pengembangan yang memiliki tahapan Analisis, Desain, Pengembangan, Pelaksanaan dan Evaluasi (Wijaya, Ying, \& Purnama, 2020). Berikut ini adalah tahapan penelitian pengembangan yang menggunakan model ADDIE :

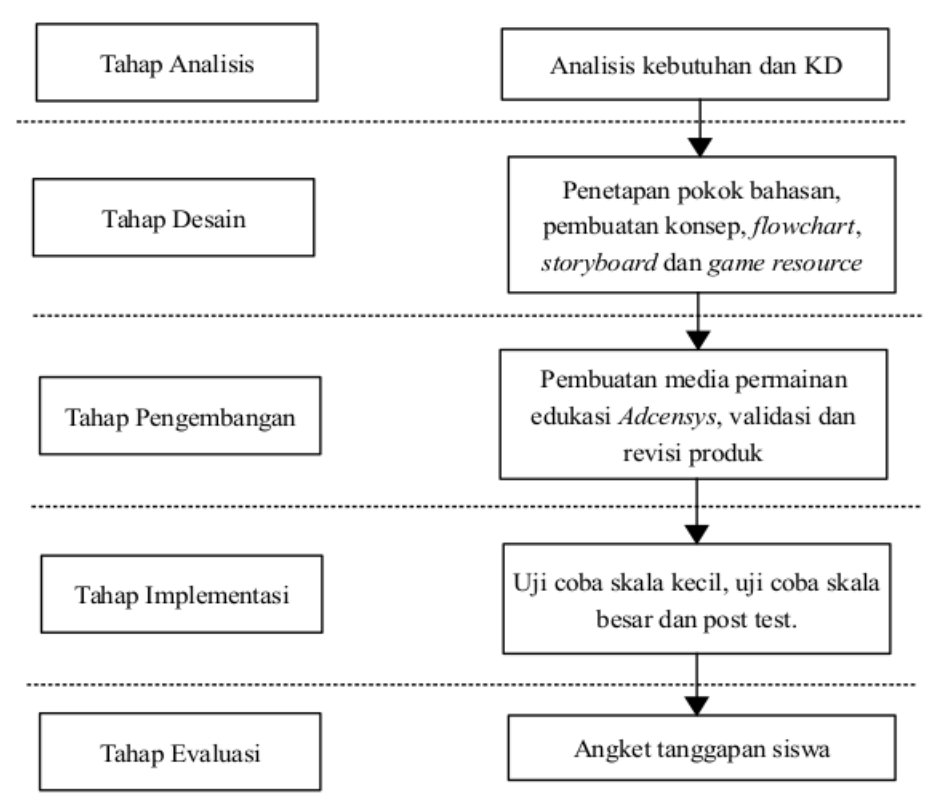

Gambar 2. Tahapan Penelitian dan Pengembangan ADDIE

\section{Subyek Penelitian}

Penelitian ini menggunakan subyek mahasiswa Pendidikan Matematika Fakultas IImu Pendidikan di UNHASY yang mengikuti mata kuliah statistik pada tahun akademik 2019/2020. Selain itu untuk subyek uji coba skala kecil menggunakan 10 mahasiswa dari prodi Pendidikan bahasa Inggris yang juga mengampu mata kuliah statistik di Fakultas IImu Pendidikan UNHASY.

\section{Teknik Pengumpulan Data}

Teknik pengumpulan data pada penelitian ini menggunakan metode angket dan metode tes. Soal tes yang sudah dikembangkan akan diujikan pada subyek uji coba skala kecil yang kemudian akan dilakukan analisis butir soal pada 5 soal yang dikembangkan. Setelah soal dinyatakan valid, reliabel, dan sensitif maka soal dikemas dan disajikan dalam microsoft power point berbasis macro VBA. Soal tes diujikan secara online dengan bantuan aplikasi Google Meet pada saat perkuliahan. Hal ini dikarenakan Indonesia masih dilanda 
pandemi Covid 19 yang diharuskan tetap stay di rumah untuk memutus penularan virus tersebut.

\section{Teknik Analisis Data}

Teknik analisis data pada penelitian ini diantaranya, uji validitas instrumen yang dilakukan oleh para ahli yaitu ahli media dan ahli materi, kemudian uji kepraktisan produk yang dilihat dari hasil respon para pengguna, serta uji efektifitas produk dengan melihat hasil belajar para mahasiswa.

Nieveen menjelaskan bahwasanya ketika melakukan penelitian pengembangan penting untuk memenuhi kualitas produk yang memenuhi kriteria kevalidan, kepraktisan, dan keefektifan (Nuryadi, \& Khuzaini, 2017).

1) Analisis Data Validitas Produk

Para ahli materi dan media memberi nilai di setiap lembar validasi hasil produk yang telah dikembangkan menggunakan software microsoft power point berbasis macro VBA. Terdapat lima kriteria pada lembar validasi instrumen, diantaranya : tidak baik (skor1), kurang baik (skor 2), cukup baik (skor 3), baik (skor 4) dan sangat baik (skor 5). Langkah-langkah dalam menganalisis data validasi adalah : 1) Merekap hasil data uji validasi dari para validator yaitu validator ahli materi dan media, 2) Menghitung mean total skor setiap indikator dari penilaian yang sudah diberikan oleh para validator dengan menggunakan rumus, 3) produk dikatakan valid jika setiap indikator/aspek yang dinilai memperoleh kriteria minimal cukup baik (skor 3).

2) Analisis Data Kepraktisan Produk

Kepraktisan produk yang sudah dikembangkan bisa dilihat berdasarkan penilaian para pengguna yaitu mahasiswa yang mengikuti perkuliahan statistik dan telah mengikuti tes untuk mengerjakan soal-soal statistik yang sudah disajikan dalam software microsoft power point berbasis macro VBA. Langkah-langkah dalam menganalisisnya yaitu dilakukan dengan cara : 1) data dikelompokkan sesuai indikator/aspek, kemudian 2) menghitung mean setiap aspek dan rata-rata total.

3) Analisis Data Keefektifan Produk

Keefektifan Produk bisa dilihat berdasarkan hasil tes belajar mahasiswa. Mahasiswa dikategorikan tuntas belajar jika mahasiswa mendapatkan nilai 
minimal 70. Adapun ketuntasan belajar secara klasikal tercapai apabila minimal $75 \%$ dari jumlah seluruh mahasiswa telah tuntas belajar. Sebelum soal diberikan kepada mahasiswa, soal-soal terlebih dahulu dilakukan Analisis butir tes untuk melihat kevalidan, kereliabilitasan, dan kesensitifan soal :

a. Validitas

Soal berada pada kategori valid jika soal yang telah dikembangkan mampu mengukur kemampuan peserta didik pada pembelajaran sesuai dengan tujuan yang sudah ditentukan. Sebuah soal mempunyai validitas tinggi apabila skor pada tiap butir soal mempunyai kesejajaran dengan skor total. Kesejajaran ini bisa diartikan dengan kolerasi sehingga untuk mengetahui validitas butir menggunakan rumus kolerasi product moment. (Sefrianto, Badrujaman, \& Komarudin, 2020).

validitas butir digunakan rumus kolerasi product moment berikut:

$$
r_{x y}=\frac{n \sum_{i=1}^{n} X_{i} Y_{i}-\left(\sum_{i=1}^{n} X_{i}\right)\left(\sum_{i=1}^{n} Y_{i}\right)}{\sqrt{\left(n \sum_{i=1}^{n} X_{i}^{2}-\left(\sum_{i=1}^{n} X_{i}\right)^{2}\right)\left(n \sum_{i=1}^{n} Y_{i}^{2}-\left(\sum_{i=1}^{n} Y_{i}\right)^{2}\right)}}
$$

Keterangan :

$\mathrm{X}=$ Skor butir

$Y=$ Skor total

$r_{x y}=$ Koefisien korelasi skor butir dan skor total

$\mathrm{N}$ = Banyaknya siswa yang mengikuti tes

Koefisien korelasi diinterpretasikan pada tabel berikut :

Tabel 1. Koefisien Korelasi

\begin{tabular}{|l|c|}
\hline Koefisien Korelasi & Interpretasi \\
\hline $0.80<r_{x y} \leq 1.00$ & Validitas butir tes sangat tinggi \\
\hline $0.60<r_{x y} \leq 0.80$ & Validitas butir tes tinggi \\
\hline $0.40<r_{x y} \leq 0.60$ & Validitas butir tes cukup \\
\hline $0.20<r_{x y} \leq 0.40$ & Validitas butir tes rendah \\
\hline $0.00<r_{x y} \leq 0.20$ & Validitas butir tes sangat rendah \\
\hline
\end{tabular}


b. Reliabilitas

Reliabilitas soal bertujuan untuk mengetahui konsistensi hasil tes. Koefisien realibitas suatu soal bisa diukur dengan menggunakan rumus alpha sebagai berikut (Amirrudin, Nasution, \& Supahar, 2021) :

$$
r_{11}(\alpha)=\left(\frac{n}{(n-1)}\right)\left(1-\frac{\sum \sigma_{i}^{2}}{\sigma_{i}^{2}}\right)
$$

Keterangan :

$r_{11}=$ reliabilitas

$\sum \sigma_{i}^{2}=$ jumlah varians tiap-tiap item

$\sigma_{i}^{2}=$ varians total

$\mathrm{n} \quad$ = banyaknya soal

Reliabilitas diinterpretasikan pada tabel berikut :

Tabel 2. Koefisien Reliabilitas

\begin{tabular}{|l|l|}
\hline Reliabilitas & Interpretasi \\
\hline $0.80<r_{11} \leq 1.00$ & Reliabilitas sangat tinggi \\
\hline $0.60<r_{11} \leq 0.80$ & Reliabilitas tinggi \\
\hline $0.40<r_{11} \leq 0.60$ & Reliabilitas cukup \\
\hline $0.20<r_{11} \leq 0.40$ & Reliabilitas rendah \\
\hline$r_{11} \leq 0,20$ & Reliabilitas sangat rendah \\
\hline
\end{tabular}

Dalam penelitian ini, tes dinyatakan reliabel jika koefsien reliabilitas tes tersebut diinterpretasikan minimal cukup.

c. Sensitivitas

Uji Sensitivitas untuk mengetahui ukuran seberapa baik butir soal itu bisa membedakan tingkat kemampuan siswa sebelum dan sesudah menerima pembelajaran. Rumus yang digunakan adalah :

$$
S=\frac{\sum s_{e s}-\sum s_{e b}}{N\left(\text { Skor }_{\text {max }}-\text { Skor }_{\text {min }}\right)}
$$

Keterangan :

$\mathrm{S}=\quad=$ Indeks sensitivitas butir soal

$\mathrm{N} \quad=$ Banyaknya siswa

$\sum S_{e s} \quad=$ Jumlah skor subjek sesudah proses pembelajaran 


$$
\begin{array}{ll}
\sum S_{e b} & =\text { Jumlah skor subjek sebelum proses pembelajaran } \\
S k o r_{\text {max }} & =\text { Skor maksimum yang dapat dicapai oleh subjek } \\
\text { Skor }_{\text {min }} & =\text { Skor minimum yang dapat dicapai oleh subjek }
\end{array}
$$

Nilai sensitivitas butir tes berkisar antara -1.00 sampai 1.00 . Butir tes dikatakan baik apabila koefisien sensitivitasnya berkisar antara 0 dan 1 . Suatu butir tes dikatakan peka (sensitif) terhadap pembelajaran jika $S \geq 0,40$ (Fatimah \& Alfath, 2019).

Sensitivitas merupakan ukuran seberapa baik butir soal itu dapat membedakan tingkat kemampuan mahasiswa sebelum menerima pembelajaran dan sesudah menerima pembelajaran.

\section{HASIL DAN PEMBAHASAN}

\section{Analisis (Analysis)}

Di lingkungan UNHASY proses evaluasi hasil belajar mahasiswa masih dilakukan secara manual berdasarkan observasi yang dilakukan pada bulan Agustus 2019. Hal ini menjadikan proses evaluasi hasil belajar kurang efisien. Terlebih lagi saat ini mahasiswa UNHASY setiap tahunnya mengalami kenaikan. Perlu dilakukan inovasi untuk menggunakan aplikasi/software yang saat ini sudah banyak tersedia. Salah satunya microsoft power point berbasis macro VBA. Aplikasi ini selain sudah ada pada semua PC, banyak yang sudah tidak asing dengan menu ini. Sehingga lebih mudah untuk mengaplikasikannya tanpa perlu menginstal ulang pada PC seperti aplikasi yang lain. Aplikasi ini menjadi salah satu solusi yang bisa dilakukan untuk meminimalisir kelemahan metode konvensional yang selama ini dilakukan di UNHASY. Selain itu dengan menggunakan VBA, proses evaluasi hasil belajar menjadi lebih interaktif dan menarik.

\section{Perancangan (Design)}

Rancangan awal produk dimulai dengan membuat beberapa Soal statistik yang memuat tiga materi, yaitu analisis regresi, analisis korelasi, dan analisis of Varians. Soal dibuat dalam bentuk pilihan ganda sebanyak 5 soal yang memiliki empat pilihan dengan 1 pilihan jawaban yang benar. Soal yang yang sudah dibuat akan dikemas ke dalam microsoft power point menggunakan macro VBA. Soal 
hanya bisa dikerjakan sebanyak satu kali, dan skor setiap mahasiswa setelah menyelesaikan soal akan langsung terlihat setelah selesai mengerjakan.

\section{Pengembangan (Develop)}

Tahapan ini dimulai dengan mengembangkan instrumen berupa soal-soal statistika berupa soal pilihan ganda yang berjumlah 5 soal dan dikemas dalam aplikasi microsoft power point berbasis Macro VBA.

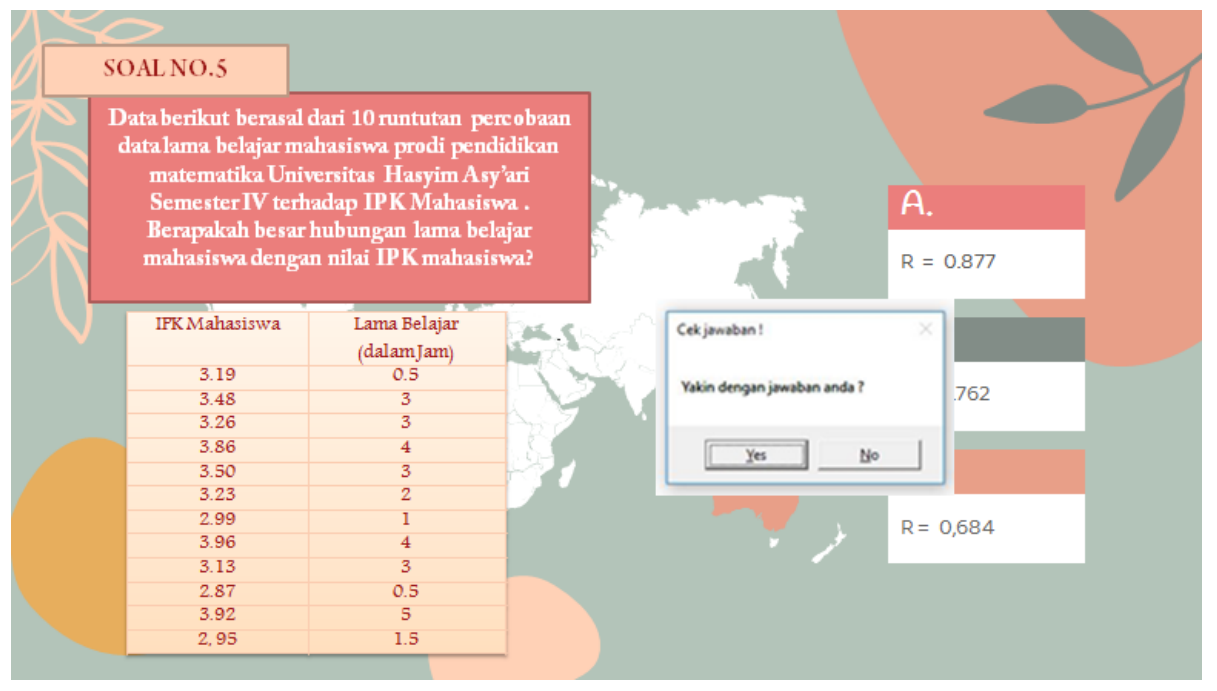

Gambar 3. Tampilan layar Microsoft Power Point Berbasis Macro Visual Basic

Instrumen yang sudah dikembangkan kemudian dilakukan validasi kepada dua validator. Validator pada penelitian ini adalah satu validator ahli materi dan satu ahli media. Hasil validasi oleh para validator berupa alat evaluasi pembelajaran menggunakan Microsoft Power Point Berbasis macro Visual basic pada mata kuliah statistik adalah sebagai berikut:

\section{- Hasil Validasi para Ahli}

\section{a. Hasil Validasi Ahli Media}

Tabel 3 menyakin hasi produk yang dikembangkan berdasarkan penilaian Ahli Media berada pada kategori valid dan sangat valid. Hal ini dikarenakan persentase penilaian yang diberikan oleh para validator berada pada rentang nilai di $80-90 \%$. 
TUNJUK AJAR: JURNAL PENELITIAN ILMU PENDIDIKAN

Volume 4, Nomor 2, 2021

P-ISSN: 2615-062X

E-ISSN: 2622-3554

http://dx.doi.org/10.31258/jta.v4i2.200-217

Tabel 3. Hasil Penilaian Kuantitatif Validator Ahli Media

\begin{tabular}{|l|l|l|l|l|}
\hline Aspek & $\begin{array}{l}\text { Penilaian } \\
\text { Validator }\end{array}$ & $\begin{array}{l}\text { Nilai } \\
\text { Maksimal }\end{array}$ & Persentase & Kategori \\
\hline Umum & 17 & 20 & $85 \%$ & Sangat Valid \\
\hline $\begin{array}{l}\text { Rekayasa } \\
\text { Perangkat } \\
\text { Lunak }\end{array}$ & 13 & 15 & $86.66 \%$ & Sangat Valid \\
\hline $\begin{array}{l}\text { Komunikasi } \\
\text { Visual }\end{array}$ & 25 & 30 & $83.33 \%$ & Valid \\
\hline Desain Media & 30 & 35 & $85.71 \%$ & Sangat Valid \\
\hline
\end{tabular}

b. Hasil Validasi Ahli Materi

Tabel 4. Hasil Penilaian Kuantitatif Validator Ahli Materi

\begin{tabular}{|l|l|l|l|l|}
\hline Aspek & $\begin{array}{l}\text { Penilaian } \\
\text { Validator }\end{array}$ & $\begin{array}{l}\text { Nilai } \\
\text { Maksimal }\end{array}$ & Persentase & Kategori \\
\hline Format & 8 & 10 & 80 & Valid \\
\hline Isi & 17 & 20 & 85 & Sangat Valid \\
\hline Bahasa & 31 & 35 & 88.57 & Sangat Valid \\
\hline
\end{tabular}

Berdasarkan Tabel 4 dapat disimpulkan bahwa produk yang dikembangkan berdasarkan penilaian ahli materi berada pada kategori valid dan sangat valid. Hal ini dikarenakan persentase penilaian yang diberikan oleh para validator berada pada rentang nilai di $80-90 \%$.

\section{Pelaksanaan (Implementation)}

Pada tahap pelaksanaan ini terlebih dahulu dilakukan uji coba skala kecil untuk mengetahui validitas, reliabilitas, dan sensitifitas soal.

- Hasil Validitas, Reliabilitas, dan Sensitifitas Butir Soal

a. Validitas

Perhitungan validitas setiap butir tes dengan menggunakan rumus korelasi product moment. Berikut ini adalah tabel hasil perhitungan validitas setiap butir soal 
Tabel 5. Hasil Nilai Validitas Tiap Butir Tes

\begin{tabular}{|c|l|l|l|l|l|}
\hline No. Soal & 1 & 2 & 3 & 4 & 5 \\
\hline$r_{x y}$ & 0.417128 & 0.559983 & 0.649569 & 0.692646 & 0.512998 \\
\hline Kriteria & CT & CT & T & T & CT \\
\hline
\end{tabular}

Dari hasil tabel 5, maka disimpulkan bahwa secara umum validitas tiap butir soal tes hasil belajar dianggap valid dan dapat digunakan tanpa revisi karena kriteria tiap butir tes berada pada kriteria Tinggi, dan Cukup Tinggi.

\section{b. Reliabilitas}

Dari hasil perhitungan reliabilitas menggunakan Microsoft Excel, diperoleh koefisien reliabilitas tes cukup tinggi yaitu $\alpha=0,502$. Artinya tes hasil belajar sudah reliabel dan bisa digunakan tanpa perlu adanya revisi lagi untuk mengukur tingkat penguasaan mahasiswa terhadap mata kuliah statistik.

\section{c. Sensitifitas}

Berdasarkan rumus sensitivitas terhadap 5 soal yang dinyatakan valid diperoleh nilai sensitivitas setiap butir tes sebagai berikut :

Tabel 6. Hasil Nilai Sensitifitas Tiap Butir Tes

\begin{tabular}{|c|l|l|l|l|l|}
\hline No. Soal & $\mathbf{1}$ & $\mathbf{2}$ & $\mathbf{3}$ & $\mathbf{4}$ & $\mathbf{5}$ \\
\hline $\boldsymbol{r}_{\boldsymbol{x} y}$ & 0.649 & 0.684 & 0.736 & 0.701 & 0.666 \\
\hline Kriteria & Sensitif & Sensitif & Sensitif & Sensitif & Sensitif \\
\hline
\end{tabular}

Setelah soal dinyatakan valid, reliabel, dan sensitif, soal yang sudah dikemas ke dalam aplikasi microsoft power point berbasis macro VBA diimplementasikan ke mahasiswa prodi pendidikan matematika yang mengampu mata kuliah statistik. 


\section{- Hasil Tes Mahasiswa}

Setelah menggunakan produk alat evaluasi berbasis IT, Hasil tes mahasiswa bisa langsung diketahui secara cepat. Dari 19 mahasiswa, sebanyak 1 mahasiswa yang mengikuti tes tidak tuntas dalam pembelajaran karena nilainya masih dibawah batas kelulusan. Namun untuk ketuntasan belajar secara klasikal tergolong tuntas, karena ketuntasan belajar yang diperoleh lebih dari $75 \%$ yaitu $94,7 \%$. Oleh karena itu, produk yang dikembangkan bisa dikatakan efektif dilihat dari hasil belajar mahasiswa baik secara individu dan secara klasikal.

\section{Evaluasi (Evaluation)}

Setelah tahap implementasi, selanjutnya dilakukan tahap evaluasi. Tahapan ini dilakukan untuk mengevaluasi produk pada setiap tahapan. Pada tahap pengembangan, dilakukan evaluasi sesuai masukan saran para validator. Salah satunya terkait audio pada produk yang bisa mengganggu para pengguna karena musik yang kurang sesuai/terlalu keras. Sehingga musik pada produk diganti dengan musik yang lebih pelan dan tidak mengganggu konsentrasi mahasiswa saat menyelesaikan soal. Selanjutnya, beberapa kata yang salah ketik sudah dibenarkan sesuai dengan EYD. Selain itu, Pada tahap evaluasi, dilakukan pemberian angket kepada para mahasiswa untuk mengetahui kepraktisan produk yang sudah digunakan. Hal ini juga dilakukan untuk memperoleh masukan dan saran dari para pengguna. Berikut hasil angket respon mahasiswa setelah menggunakan produk :

Tabel 7. Hasil Angket Respon Mahasiswa

\begin{tabular}{|l|c|c|}
\hline \multicolumn{1}{|c|}{ Aspek } & \% Respon Positif & \%Respon Negatif \\
\hline $\begin{array}{l}\text { Respon Mahasiswa pada software } \\
\text { yang digunakan }\end{array}$ & $88.15 \%$ & $11.84 \%$ \\
\hline $\begin{array}{l}\text { Respon Mahasiswa terhadap alat } \\
\text { evaluasi berbasis IT }\end{array}$ & $96.05 \%$ & $3.94 \%$ \\
\hline Respon Mahasiswa terhadap Soal & $96.05 \%$ & $3.94 \%$ \\
\hline $\begin{array}{l}\text { Respon Mahasiswa terhadap } \\
\text { Dosen pada saat proses evaluasi }\end{array}$ & $94.73 \%$ & $5.26 \%$ \\
\hline $\begin{array}{l}\text { Respon Mahasiswa terhadap } \\
\text { keberlanjutan menggunakan alat } \\
\text { evaluasi berbasis IT }\end{array}$ & $100 \%$ & $0 \%$ \\
\hline \multicolumn{1}{|c|}{ Rata-Rata } & $94.07 \%$ & $5.92 \%$ \\
\hline
\end{tabular}


Berdasarkan tabel 7 dapat disimpulkan bahwa hasil respon mahasiswa terhadap komponen produk yang sudah dikembangkan berada pada nilai yang positif, hal ini dikarenakan respon positif mahasiswa yang mencapai nilai $>80 \%$. Selain itu minat mahasiswa untuk menggunakan produk ini lagi mencapai $100 \%$ yang artinya semua mahasiswa sangat berminat dan antusias menggunakan produk yang sudah dikembangkan. Maka dari itu, berdasarkan hasil respon mahasiswa yang bernilai positif (lebih besar dari 80\%), maka produk alat evaluasi layak digunakan karena sudah memenuhi kriteria valid, praktis, dan efektif.

\section{SIMPULAN}

Produk Soal statistika menggunakan software yang berbasis IT yaitu Microsoft Power Point Berbasis Macro Visual Basic yang telah dikembangkan menggunakan model pengembangan ADDIE. Melalui kelima tahapan ADDIE diperoleh kesimpulan bahwa produk merupakan produk yang valid digunakan dilihat dari hasil penilaian para validator yang berada pada kategori valid dan sangat valid, Produk juga praktis untuk digunakan dilihat dari hasil penilaian positif mahasiswa yang rata-rata lebih dari $80 \%$ pada setiap aspek yang dinilai, Produk juga dikatakan efektif karena Hasil tes mahasiswa menunjukkan persentase ketuntasan klasikal sebesar $94,7 \%$. Selain itu hasil analisis butir soal statistika juga menyatakan bahwa soal statistika yang sudah dikembangkan dinyatakan valid, reliable, dan sensitif. Berdasarkan pedoman kriteria kelayakan, maka secara keseluruhan produk berupa soal statistika yang disajikan dalam software Microsoft Power Point Berbasis Macro Visual Basic dinyatakan layak untuk digunakan.

\section{DAFTAR PUSTAKA}

Almutairi, T.S., \& Shraid, N. F. (2021). Teacher evaluation by different internal evaluators: Head of departments, teachers themselves, peers and students. International Journal of Evaluation and Research in Education (IJERE) Vol. 10, No. 2, June 2021, pp. 588 596 DOI: 10.11591/ijere.v10i2.20838

Amirrudin, M., Nasution, K., \& Supahar. (2021). Effect of Variability on Cronbach Alpha Reliability in Research Practice. Jurnal Matematika, Statistika, dan 
Komputasi. Vol. 17, No. 2, 223-230, January, 2021 DOI: 10.20956/jmsk.v17i2.11655

Anomeisa, A.B. \& Ernaningsih, D. (2020). Media Pembelajaran Interaktif menggunakan PowerPoint VBA pada Penyajian Data Berkelompok. Jurnal Pendidikan Matematika Raflesia Vol. 05 No. 01, Maret 2020 https://ejournal.unib.ac.id/index.php/jpmr

Chotimah, S., Bernard, M., \& Wulandari, S. M. (2018). Contextual approach using VBA learning media to improve students' mathematical displacement and disposition ability. IOP Conf. Series: Journal of Physics: Conf. Series 948 (2018) 012025 doi :10.1088/1742-6596/948/1/012025

Dilmurodovna, M., N. (2020). Use of Macros in VBA Programming Language in Power Point. International Journal of Progressive Sciences and Technologi Vol. 23 No. 1 October 2020, pp. 09

Fatimah, I. U. \& Alfath, K. (2019). Analisis Kesukaran Soal, Daya Pembeda Dan Fungsi Distraktor. Jurnal Komunikasi dan Pendidikan Islam, Volume 8, Nomor 2, Desember 2019

Febriyanti, D., \& Putra, Z. H. (2020). Development of 3-Dimensional Snake and Ladder Game: Implementation with Second Grade Students of SDN 37 Pekanbaru. JURNAL PAJAR (Pendidikan dan Pengajaran),4(6), 1140 1151 http://dx.doi.org/10.33578/pjr.v4i6.8107

Hasana, S. N., \& Alifiani, A. (2019). Multimedia Development Using Visual Basic For Application (VBA) To Improve Students' Learning Motivation In Studying Mathematics Of Economics. Indonesian Journal of Mathematics $\begin{array}{llll}\text { education } & \text { Vol } & 2, & \text { No }\end{array}$ (2019)

DOI: http://dx.doi.org/10.31002/ijome.v2i1.1230

Iqbal, Wan M G, Fadilah, Raudhatul, \& Hadiarti, Dini. (2018). Pengembangan alat Evaluasi Berbasis Wondershare Quiz Creator pada Materi Koloid Kelas XI di SMA Koperasi Pontianak. Jurnal Ar-Razi Vol. 6 No.1 Februari 2018

Jalinus, J., \& Alim, J. A. (2018). Pengembangan media pembelajaran matematika interaktif berbasis komputer pada topik bilangan bulat untuk siswa SD pendidikan matematika FKIP UNRI. Tunjuk Ajar: Jurnal Penelitian Pendidikan, 1(1), 14 - 26. http://dx.doi.org/10.31258/jta.v1i1.14-26 
Kasali, R. (2018). Disruption. Jakarta : PT Gramedia Pustaka Utama.

Lee, S. M., \& Trimi, S. (2018) Innovation for creating a smart future. Journal of Innovation \& Knowledge Volume 3, Issue 1, January-April 2018, Pages 1-8 https://doi.org/10.1016/j.jik.2016.11.001

Nuryadi, \& Khuzaini, N. (2017). Virtual Mathematics Media Effectiveness Based Teams Game Tournament Reviewed From Cognitive Load Theory. Jurnal Mercumatika : Jurnal Penelitian Matematika dan Pendidikan Matematika ISSN: 2548-1819 Vol. 2, No 1, Oktober 2017, pp. 57-68

Putra, Z. H., Wulandari, W., Alpusari, M., \& Hermita, N. (2021). Developing a Dynamic Number Card Game to Support Students' Number Sense: A Preliminary Study. Proceeding of 1st International Conference on Technology Enhanced Learning in Higher Education (TELE), IEEE.

Rahayu, E. N. (2021) An evaluation of e-learning implementation during COVID-19 emergency response period. International Journal of Evaluation and Research in Education (IJERE)Vol 10, No 4: December 2021 http://doi.org/10.11591/ijere.v10i4.20751

Ruqoyyah, S., Murni, S., \& Wijaya, T. T. (2020). The Effect of VBA for Microsoft Excel as Teaching Material to Improve Prospective Elementary School Teachers' Mathematical Conceptual Understanding. Mimbar Sekolah Dasar, 7(2), 251-268. https://doi.org/10.17509/mimbar-sd.v7i2.26494

Sefrianto, Badrujaman, A., \& Komarudin. (2020). The Validity Of Instruments As Measuring Instrument For The Evaluation On Students Job Training Program At Smk Negeri 1 Cariu Bogor Regency. Journal of Indonesian student Assesment and Evaluation. JISAE. Volume 6 Number 2 September 2020

Serdyukov, P. (2017). Innovation in education: what works, what doesn't, and what to do about it?. Journal of Research in Innovative Teaching \& Learning., vol. 10, no. 1, pp. 4-3

Sharpe, T. (2018). Ethical issues in domestic building performance evaluation studies," Build. Res. Inf., vol. 47, no. 3, pp. 318-329, 2019, doi: 10.1080/09613218.2018.1471868.3, 2017, doi: 10.1108/jrit-10-2016-0007 
Wahyuni, N., \& Ananda, L. J. (2021). Development of Thematic Teaching Materials Based on Discovery Learning in Elementary School. Journal of Teaching and Learning in Elementary Education, 4(1), 122-130. http://dx.doi.org/10.33578/jtlee.v4i1.7861

Widyastuti, E., \& Susiana. (2019). Using The ADDIE Model To Develop Learning Material For Actuarial Mathematics. IOP Conf. Series: Journal of Physics: Conf. Series 1188 (2019) 012052 IOP Publishing doi:10.1088/1742$6596 / 1188 / 1 / 012052$

Wijaya, T. T., Zulfah, Z., Hidayat, A., Akbar, P., Arianti, W., \& Asyura, I. (2020). Using VBA for microsoft excel based on 6-questions cognitive theory in teaching fraction. Journal of Physics: Conference Series, 1657(1), 012078. https://doi.org/10.1088/1742-6596/1657/1/012078

Wijaya, T. T., Ying, Z., \& Purnama, A. (2020). Using Hawgent dynamic mathematics software in teaching trigonometry. International Journal of Emerging Technologies in Learning, 15(10). https://doi.org/10.3991/ijet.v15i10.13099

Wijaya, T.T., Ying, Z., Cunhua, L., \& Zulfah. (2020). Using Vba Learning Media To Improve Students' Mathematical Understanding Ability. Journal On Education Volume 02, No. 02, Februari 2020, hal. 245-254 